\title{
Anti-microbial and Anti-oxidant Activity of Watermelon (Citrullus lanatus) Fruit and Watermelon Seed
}

\author{
Perihan AKBAŞ ${ }^{*}$, Özlem GÜRSOY KOL ${ }^{2}$, Abdurrahman GÜRBÜZ ${ }^{1}$ and Sevda MANAP² \\ ${ }^{1}$ Atatürk Vocational School of Health Services, Kafkas University, Kars, Turkey, +90 47422511 50, \\ perihanakbas36@gmail.com \\ ${ }^{2}$ Chemistry Department, Science Faculty, Kafkas University, Kars, Turkey, +90 47422511 50, \\ ozlemgursoy@gmail.com \\ *Corresponding author \\ Recieved: $10^{\text {th }}$ Ocotober 2016 \\ Accepted: $2^{\text {nd }}$ February 2016 \\ DOI: http://dx.doi.org/10.18466/cbujos.302659
}

\begin{abstract}
Watermelon (Citrullus lanatus) flesh and seeds were dried and pulverized, and their extracts were diffused to sterile discs for the evaluation of anti-microbial activity. The disc-diffusion technique was used to assess anti-bacterial activity against Bacillus subtilis, Escherichia coli, Pseudomonas aeruginosa, Pasteurella multocida, Yersinia enterocolitica, Serratia marcescens, Klebsiella pneumoniae, Xanthomonas campestris, Staphylococcus aureus. Anti-fungal activity against the yeasts Candida albicans and Rhodotorula glutinis was also examined. Standard anti-biotics were also tested as controls.

Watermelon flesh and seed extracts were found to be effective against gram-positive and gram-negative bacteria and yeasts. The extracts were also screened for anti-oxidant activity using the 2,2-diphenyl-1-picryl-hydrazyl (DPPH) freeradical-scavenging assay, total reducing ability using the $\mathrm{Fe}^{3+}-\mathrm{Fe}^{2+}$ transformation method and ferrous ion ( $\mathrm{Fe}^{2+}$ )chelating activity. Butylated hydroxyanisole (BHA), butylated hydroxytoluene (BHT), ethylenediaminetetraacetic acid and $\alpha$-tocopherol were used as reference anti-oxidant radical scavenger compounds.

The most potent anti-bacterial activity was demonstrated by watermelon-ethanol extract (inhibition zone $30 \mathrm{~mm}$ ) against K. pneumoniae, and the most potent anti-fungal activity was demonstrated by watermelon-acetone extract (inhibition zone $26 \mathrm{~mm}$ ) against $R$. glutinis. Watermelon-ethanol and watermelon seed-ethanol extracts both demonstrated marked anti-oxidant activity.

These results highlight that watermelon fruit and seed extracts have potential for the development of efficient, safe and cost-effective natural anti-oxidant compounds for application in the functional food industries.
\end{abstract}

Key Words: anti-microbial, anti-oxidant, Citrullus lanatus, watermelon, watermelon seed.

\section{Introduction}

Although the concept of anti-microbial activity became popular in the 1930s, anti-microbial resistance has emerged after the introduction of newer anti-microbial compounds.[1] This has prompted a search for alternative anti-microbial agents in the hope that novel products will trigger a decrease in anti-microbial resistance. Research into the antioxidant and anti-microbial activity of various common foods has already been conducted; for example, rich sources of proteins, such us; date, grape seed, pumpkin seed, hawthorn and absinthe have been analysed.[2-6] However, the analysis of watermelon fruit and seeds for new anti-microbial agents has not been reported. Therefore, the work presented here is a novel study.

The importance of controlling antioxidant activity has increased because of the consumption of foods containing significant amounts of unsaturated fatty acids. The interest in and use of anti-oxidants has 
CBÜ F Bil. Dergi., Cilt 13, Sayı 1, 2017, 139-147 s

also increased as they can extend the shelf-life of food items, particularly those with high fat content. The use of synthetic anti-oxidants such as butylated hidroksiyanosil (BHA) and butylated hydroxytoluene (BHT), is limited because of their suspected carcinogenic properties.[7] Therefore, there has been a substantial increase in studies on natural plant-based anti-oxidants.[8]

There is a growing interest in substances possessing natural anti-bacterial activity and oxidation inhibition effects such as plants, herbs and spices. They have characteristic flavours and show antioxidant activity in addition to anti-microbial activity. [9] It is now well known that certain plant extracts (e.g., grape seed and green tea) have antimicrobial properties and contain catechins. Thus, the search for natural anti-oxidants and antimicrobial products is ongoing.[10]

In this study, as part of the search for alternative herbal anti-oxidants, we aimed to compare the antioxidant activity of freshly squeezed fruit juices and commercial fruit juices.[11] Anti-oxidant activity has been investigated in flax seed, bulbous plants, tomato (Solanum betaceum Cav.), salvia (Salvia officinalis), plants with leaves consumed as either salad or spices.[12-16]

Watermelon is one of the substantially underutilized fruits grown in the warmer parts of the world. Watermelon seeds are high in protein content and contain the complete range of essential amino acids. They are said to also contain considerable amounts of minerals which assist in the growth and development of a healthy body.[17] Watermelon seeds are used for oil production in India and some African countries.[18] Watermelon is cultivated in Turkey, and watermelon seeds are dried and eaten as a snack in South Turkey.

\section{Materials and Methods}

All chemicals and solvents used were of analytical purity. BHT was purchased from Merck. Ferrous chloride, $\alpha$-tocopherol, 1,1-diphenyl-2-picrylhydrazyl (DPPH), 3-(2-pyridyl)-5,6bis(phenylsulfonic acid)-1,2,4-triazine (ferrozine), BHA, ethylenediaminetetraacetic acid and trichloroacetic acid were bought from Sigma. The anti-
CBU J. of Sci., Volume 13, Issue 1, 2017, p 139-147 microbial activity of watermelon flesh and seeds was evaluated on seven different microorganisms obtained from the microbiology laboratories of Atatürk Health Services Vocational School, Kafkas University (Kars, Turkey) and the Biology Department, Atatürk University (Erzurum, Turkey). Antibacterial activity was tested against two grampositive bacteria (Bacillus subtilis ATCC 6633 and Staphylococcus aureus ATCC 25213), and seven gram-negative bacteria (Escherichia coli ATCC 25922, Pseudomonas aeruginosa ATCC 9027, Serratia marcescens ATCC 14756, Yersinia enterocolitica ATCC 27729, Klebsiella pneumoniae ATCC 4352, Xanthomonas campestris ATCC 33913 and Pasteurella multicoda ATCC 6538). Two species of yeast, Candida albicans ATCC 10231 and Rhodotorula glutinis ATCC 28052 were used as indicator microorganisms to detect anti-fungal activity.

\subsection{Preparation of extracts}

Watermelons were purchased from a local market. The fruit was separated from seeds and peel and was then washed thoroughly with distilled water. Watermelon fruit and seeds were dried at $50^{\circ} \mathrm{C}$ until constant weight was reached, and they were powdered. Seperate preparations of fruit and seed were made using a Waring blender. Different solutions were made by adding petroleum ether, water, ethanol and acetone solvents in a powder: solvent ratio of 1:20. The solutions were incubated for $8 \mathrm{~h}$ in a turbulent water bath at $50^{\circ} \mathrm{C}$. Then they were centrifuged for 15 mins at $5000 \mathrm{rpm}$ before filtering through Watman filter paper no 1 . Solvents were evaporated at $60^{\circ} \mathrm{C}$ and the extracts obtained were loaded onto empty, sterile, filter-paper discs.

\subsection{Preparation of microorganism culture and anti-microbial disc-diffusion assays}

We used the agar-disc-diffusion method described to screen the extracts for anti-microbial activity.[19, 20] Bacterial stock cultures were prepared by inoculating Mueller-Hinton agar plates with commercial bacteriological loops containing the test organisms; these cultures were then incubated the plates at $37^{\circ} \mathrm{C}$ for $24 \mathrm{~h}$. Fungal stock cultures were similarly prepared, using Sabouraud Dextrose Agar and incubating at $25^{\circ} \mathrm{C}$ for $24-48 \mathrm{~h}$. Bacterial suspensions were prepared in nutrient 
CBÜ F Bil. Dergi., Cilt 13, Sayı 1, 2017, 139-147 s

broth and fungal suspensions in Sabouraud dextrose broth, then incubated at $37^{\circ} \mathrm{C}$ for $24 \mathrm{~h}$ and at $25^{\circ} \mathrm{C}$ for $48 \mathrm{~h}$, respectively. The turbidity of each culture was adjusted to obtain a similar optical density to that of McFarland 0.5 standard. To perform the disc-diffusion assays, a sterile filter-paper disc (6 $\mathrm{mm}$ in diameter) was impregnated with an extract and placed onto an inoculated agar plate under slight pressure. Ampicillin (20 $\mu \mathrm{g} /$ disc) and erythromycin $(10 \mu \mathrm{g} /$ disc $)$ were used as positive controls, whereas sterilized distilled water, ethanol, petroleum ether and acetone were used as negative controls. Bacteria-inoculated plates were incubated at $37^{\circ} \mathrm{C}$ for $24 \mathrm{~h}$, and yeast-inoculated plates were incubated at $25^{\circ} \mathrm{C}$ for $48 \mathrm{~h}$. Following incubation, anti-microbial activity was evaluated by measuring the diameter ( $\mathrm{mm}$ ) of any observed inhibition zone, including that of the disc. Three independent experiments were performed for each assay, and data was collected for each in order to determine averages, which are presented here.

\subsection{Determination of Reducing Power}

The reducing power of the watermelon extracts was determined according to the method of Oyaizu (1958).[21] Different concentrations of the samples (20-100 $\mu \mathrm{g} / \mathrm{mL})$ in $1 \mathrm{~mL}$ of distilled water were mixed with phosphate buffer $(2.5 \mathrm{~mL}, 0.2 \mathrm{M}$, $\mathrm{pH}=6.6)$ and potassium ferricyanide $(2.5 \mathrm{~mL}, 1 \%)$. The mixture was incubated at $50^{\circ} \mathrm{C}$ for $20 \mathrm{~min}$ and afterwards a portion $(2.5 \mathrm{~mL})$ of trichloroacetic acid $(10 \%)$ was added to the mixture, which was centrifuged for $10 \mathrm{~min}$ at $1000 \mathrm{xg}$. The upper layer of solution $(2.5 \mathrm{~mL})$ was mixed with distilled water $(2.5$ $\mathrm{mL})$ and $\mathrm{FeCl}_{3}(0.5 \mathrm{~mL}, 0.1 \%)$, and then the absorbance at $700 \mathrm{~nm}$ was measured in a spectrophometer. Higher absorbance of the reaction mixture indicated greater reducing power.

\subsection{Determination of DPPH Free Radical Scav- enging Activity}

Free radical scavenging activity of the watermelon extracts was measured via DPPH by using the method of Blois (1986).[22] Briefly, $0.1 \mathrm{mM}$ solution of DPPH. in ethanol was prepared, and this solution $(1 \mathrm{~mL})$ was added to $1,5 \mathrm{~mL}$ of extracts at different concentrations $(50-50 \mu \mathrm{g} / \mathrm{mL})$. The mixture was shaken vigorously and allowed to remain at
CBU J. of Sci., Volume 13, Issue 1, 2017, p 139-147 the room temperature for $30 \mathrm{~min}$. Then, the absorbance was measured at $517 \mathrm{~nm}$ in a spectrophometer. The lower absorbance of the reaction mixture indicated higher free radical scavenging activity. The DPPH concentration $(\mathrm{mM})$ in the reaction medium was calculated from the following calibration curve and determined by linear regression (R: 0.997):

Absorbance $=(0.0003 \times \mathrm{DPPH} \cdot)-0.0174$

The capability to scavenge the DPPH radical was calculated by using the following equation: $\mathrm{DPPH}$. scavenging effect $(\%)=\left(A_{0}-A_{1} / A_{0}\right) \times 100$, where $A_{0}$ is the absorbance of the control reaction, and $A_{1}$ is the absorbance in the presence of the samples or standards.

\subsection{Determination of Ferrous Ions Chelating Ac- tivity}

The chelation of ferrous ions by the watermelon extracts and standards was estimated by the method of Dinis et al (1994).[23] Shortly, the extracts (20$100 \mu \mathrm{g} / \mathrm{mL}$ ) were added to a $2 \mathrm{mM}$ solution of $\mathrm{FeCl}_{2}$ $(0.05 \mathrm{~mL})$. The reaction was initiated by the addition of $5 \mathrm{mM}$ ferrozine $(0.2 \mathrm{~mL})$, and then the mixture was shaken vigorously and left remaining at the room temperature for $10 \mathrm{~min}$. After the mixture had reached equilibrium, the absorbance of the solution was measured at $562 \mathrm{~nm}$ in a spectrophotometer. All tests and analyses were carried out in triplicate and averaged. The percentage of inhibition of ferrozine-Fe ${ }^{2+}$ complex formation was given by the formula: Inhibition $\%=\left(\mathrm{A}_{0}-\mathrm{A}_{1} / \mathrm{A}_{0}\right) \times 100$, where $A_{0}$ is the absorbance of the control, and $A_{1}$ is the absorbance in the presence of the samples or standards. The control did not contain compound or standard.

\subsection{Statistical Analysis}

The antioxidant and antimicrobial tests were conducted in triplicate and the results were expressed as mean \pm standard error (SD) of the mean. Analysis of variance (ANOVA), tests were applied using Statistical Package for the Social Sciences (SPSS version 20.0) for comparisons of variance and means, and differences were considered significant at $P \leq 0.05$. 
CBÜ F Bil. Dergi., Cilt 13, Sayı 1, 2017, 139-147 s

\section{Results and Discussion}

\subsection{Anti-microbial disc-diffusion assays}

The anti-microbial activities of the watermelon and seed extracts against the various bacteria and fungi were assessed by observing the presence or absence of inhibition zones and their diameters.

The diameters of the inhibition zones (including the disc diameter) are displayed in Table 1. The results show various levels of anti-microbial activity and degrees of germ sensitivity amongst the eight extracts. They reveal that the extracts inhibited microorganism growth, creating inhibition-zone diameters ranging $10-18 \mathrm{~mm}$ for gram-positive bacteria and 10-30 $\mathrm{mm}$ for gram-negative bacteria.

All watermelon fruit extracts obtained using ethanol, water and acetone displayed anti-microbial activity against test bacteria and yeast, but only the petroleum-ether extract demonstrated antimicrobial activity against $B$. subtilis and $R$. glutinis yeast (inhibition zone $8-30 \mathrm{~mm}$ ). Only the water extract of watermelon and the ethanol extract of watermelon seed showed anti-microbial activity against $X$. campestris. The anti-bacterial and antifungal effect of the watermelon-petroleum-ether extract and watermelon seed-acetone extract were too low for determination.

The results from the anti-bacterial assays involving gram-positive bacteria reveal that the strongest activity was demonstrated by the watermelon-
CBU J. of Sci., Volume 13, Issue 1, 2017, p 139-147 ethanol extract against K. pneumoniae (inhibition zone $30 \mathrm{~mm}$ ), followed by the activity of the same extract against $E$. coli (inhibition zone $26 \mathrm{~mm}$ ) and then the activity of the watermelon-acetone extract, which was similar in magnitude to the activity against R. glutinis (inhibition zone $26 \mathrm{~mm}$ ) and $K$. pneumoniae (inhibition zone $25 \mathrm{~mm}$ ).

For watermelon seed extracts, the maximal activity was observed for the seed-water extract against $E$. coli (inhibition zone $22 \mathrm{~mm}$ ), followed by the same extract against K. pneumoniae (inhibition zone 20 $\mathrm{mm})$.

The watermelon-petroleum-ether extract displayed the lowest overall level of activity, with inhibition zones on

B. subtilis and R. glutinis of just $10 \mathrm{~mm}$. The inhibition zone shown by the watermelon-acetone extract on S. marcescens was just $10 \mathrm{~mm}$. The same result was observed for the watermelon-ethanol extract on S. aureus and the water extract on B. subtilis (inhibition zone $10 \mathrm{~mm}$ ). The lowest activity for watermelon seed extracts was demonstrated by the water extract against $S$. marcescens, with an inhibition zone of just $8 \mathrm{~mm}$.

The results presented in Table 1 clearly show that watermelon and its seed extracts demonstrated anti-microbial activity against the tested bacteria and yeasts.

Table 1. Results of anti-microbial disc-diffusion assays for the eight watermelon extracts

\begin{tabular}{|c|c|c|c|c|c|c|c|c|c|c|}
\hline \multirow{3}{*}{ Test microorganism } & \multicolumn{10}{|c|}{ İnhibition zones (mm) } \\
\hline & \multicolumn{10}{|l|}{ Extracts } \\
\hline & W. Wat. & W. Eth. & W. Ace. & W. Pet. & WS. Wat. & WS. Eth. & WS. Ace. & WS. Pet. & A1 & A2 \\
\hline B. subtilis & $10 c$ & $15 a$ & $15 a$ & $10 \mathrm{c}$ & - & $10 \mathrm{c}$ & - & $13 b$ & $15 a$ & $10 \mathrm{c}$ \\
\hline S. marcescens & $12 c$ & $15 b$ & $10 \mathrm{~d}$ & - & $8 \mathrm{e}$ & - & - & - & $12 \mathrm{c}$ & $20 \mathrm{a}$ \\
\hline E.coli & $20 c$ & $26 b$ & $22 c$ & - & $22 c$ & - & - & - & $30 a$ & $30 \mathrm{a}$ \\
\hline Y. enterocolitica & $20 a$ & - & $21 \mathrm{a}$ & - & $14 \mathrm{~b}$ & - & - & - & - & $20 \mathrm{a}$ \\
\hline K. pneumoniae & $13 \mathrm{e}$ & $30 \mathrm{a}$ & $25 b$ & - & $20 c$ & - & - & - & $12 \mathrm{e}$ & $16 \mathrm{~d}$ \\
\hline
\end{tabular}


CBÜ F Bil. Dergi., Cilt 13, Sayı 1, 2017, 139-147 s

\begin{tabular}{|c|c|c|c|c|c|c|c|c|}
\hline P. aeruginosa & $18 b$ & $23 a$ & $20 b$ & - & - & $10 \mathrm{~d}$ & - & - \\
\hline P. multocida & $12 b$ & $15 \mathrm{a}$ & $12 b$ & - & - & $10 \mathrm{c}$ & - & - \\
\hline S. aureus & $18 \mathrm{a}$ & $10 \mathrm{c}$ & $13 b$ & - & - & - & - & - \\
\hline X. campestris & - & $12 b$ & - & - & $15 a$ & - & - & - \\
\hline C. albicans & $18 b$ & $18 b$ & $14 \mathrm{c}$ & - & - & $12 d$ & $12 \mathrm{~d}$ & $14 c$ \\
\hline R. glutinis & $12 \mathrm{~d}$ & $20 c$ & $26 b$ & $10 \mathrm{~d}$ & $10 \mathrm{~d}$ & - & - & $10 \mathrm{~d}$ \\
\hline \multicolumn{9}{|c|}{ Wat.: Water; Eth.: Ethanol; Ace.:Aceton Pet.: Petroleum ether; } \\
\hline \multicolumn{9}{|c|}{ W.: Watermelon fruit; WS.: Watermelon seed } \\
\hline \multicolumn{9}{|c|}{ A1: Erythromycin10 mg; A2: Ampicillin 20 mg } \\
\hline
\end{tabular}

The extracts obtained from watermelon fruit and seed demonstrated anti-fungal effects. The strongest activity was demonstrated by the watermelonacetone extract towards $R$. glutinis (inhibition zone $26 \mathrm{~mm}$ ), followed by that of the watermelonethanol extract (inhibition zone $20 \mathrm{~mm}$ ). Against $C$. albicans, the watermelon-water and watermelonethanol extracts produced the greatest inhibition zones (inhibition zone $18 \mathrm{~mm}$ ).

All bacteria and fungi in this study, except for $X$. campestris and $Y$. enterocolitica, which showed resistance to erythromycin, demonstrated sensitivity to erythromycin and ampicillin anti-biotics. Unlike the extracts, ampicillin was able to penetrate all the gram-positive and gram-negative bacteria. This may be attributed to the fact that the watermelon and seed extracts represented a complex mixture of components, in comparison to the purity of the anti-biotic.[24,6]

B. subtilis was as sensitive to the watermelonethanol and watermelon-acetone extracts as erythromycin (inhibition zones $15 \mathrm{~mm}$ for both), and these zones were larger than those produced by ampicillin (inhibition zone $10 \mathrm{~mm}$ ). The watermelon-ethanol extract produced a greater inhibition zone against $S$. marcescens (inhibition zone $15 \mathrm{~mm}$ ) than erythromycin. The watermelon-ethanol extract produced a greater inhibition zone than that of either of the anti-biotics, on K. pneumoniae. In addition, $P$. aeruginosa was more sensitive to watermelon-ethanol, watermelon-acetone and watermelon-water extracts than the tested anti-biotics.
Erythromycin produced the greatest inhibition zone against both species of fungi $(30 \mathrm{~mm})$. Results for C. albicans revealed that the watermelonethanol and water extracts created wider inhibition zones than ampicillin, and the watermelon-acetone extract zone was of the same diameter on R. glutinis was more sensitive to the watermelon-acetone extract than to ampicillin.

In this context, anti-microbial activity appears not to be dependent on whether the tested bacteria are gram-negative or gram-positive or have a particular shape. It is demonstrated here that extracts of watermelon fruit and seed are anti-bacterial against both gram-positive bacteria (B. subtilis and $S$. aure$u s)$ and gram-negative bacteria (Y. enterocolitica, $P$. multocida, $P$. aeruginosa, X. campestris, K. pneumoniae, E. coli and S. marcescens). The extracts also demonstrated anti-fungal properties.[25, 6] The extracts generated even higher inhibition zones for the tested fungi (C. albicans and R. glutinis) than standard erythromycin anti-biotic. The reason for this could be that polyphenols exhibit a strong anti-fungal effect.[26, 27] Other studies have demonstrated the anti-microbial effect of flavonoids against grampositive or gram-negative bacteria, particularly the flavones, flavonols, flavanones, anthocyanidins and flavins, which possess significant anti-bacterial activities.[28]

According to the results we obtained, watermelon extracts were more effective than watermelon seed extracts against the test bacteria and yeast. The extracts of watermelon and its seeds in this study 
CBÜ F Bil. Dergi., Cilt 13, Sayı 1, 2017, 139-147 s

were both anti-bacterial and anti-fungal. These findings provide useful knowledge about the value of what we consume in our daily life, and of the fruits grown in our country.

\subsection{Total reductive capability using the potassi- um ferricyanide reduction method}

The reductive capabilities of extracts were assessed by the extent of conversion of the $\mathrm{Fe}^{3+} /$ ferricyanide complex to the $\mathrm{Fe}^{2+} /$ ferrous form. Therefore, $\mathrm{Fe}^{2+}$ can be monitored by measuring the formation of Perl's Prussian blue at 700 nm.[29] The reducing powers of the samples were observed at different concentrations, and results were compared with BHA, BHT and $\alpha$-tocopherol. As shown from Figure 1, watermelon-ethanol and watermelon-water extracts had effective and powerful reducing power using the potassium ferricyanide reduction method when compared to the standard antioxidants. The reducing power of all extracts (except watermelonpetroleum ether, watermelon seed-petroleum ether) BHA, BHT and $\alpha$-tocopherol increased steadily with increasing concentration of samples. Reducing power of the extracts and the standards were found as following order: BHA $>$ watermelonethanol $>$ watermelon-water $>$ BHT $>\alpha$-tocopherol $>$ watermelon seed-ethanol $>$ watermelon seedacetone $>$ watermelon-acetone $>$ watermelon seedwater, at the highest concentration.

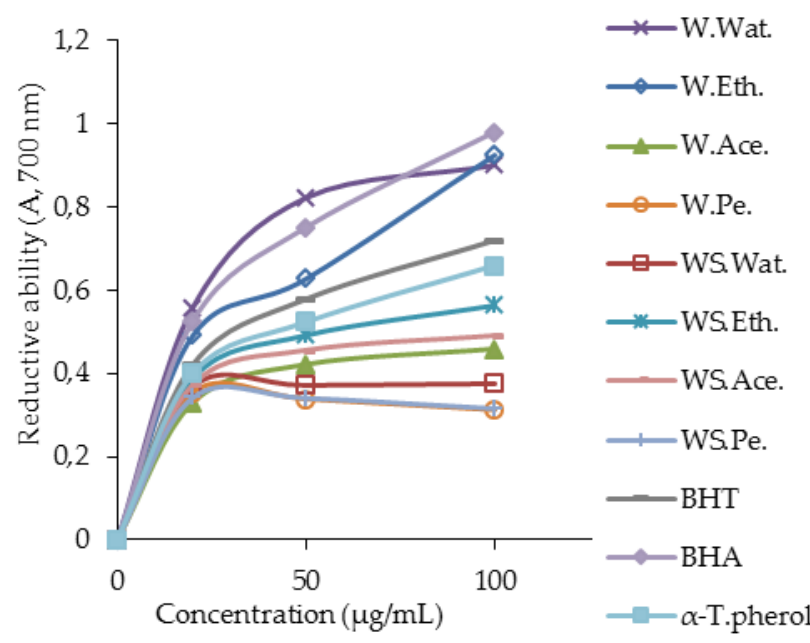

Figure 1. Total reductive potential of different concentrations of extracts, BHT, BHA and $\alpha$ -
CBU J. of Sci., Volume 13, Issue 1, 2017, p 139-147 tocopherol.

\subsection{DPPH· radical scavenging activity}

Antioxidant properties, especially radical scavenging activities, are very important due to the deleterious role of free radicals in foods and in biological systems. Excessive formation of free radicals accelerates the oxidation of lipids in foods and decreases food quality and consumer acceptance.[30, 31] The model of scavenging the stable DPPH radical is a widely used method to evaluate antioxidant activities in a relatively short time compared with other methods. The effect of antioxidants on DPPH radical scavenging was thought to be due to their hydrogen donating ability.[32] DPPH is a stable free radical and accepts an electron or hydrogen radical to become a stable diamagnetic molecule.[33] The reduction capability of DPPH radicals was determined by decrease in its absorbance at $517 \mathrm{~nm}$ induced by antioxidants. The absorption maximum of a stable DPPH radical in ethanol was at $517 \mathrm{~nm}$. The decrease in absorbance of DPPH radical was caused by antioxidants because of reaction between antioxidant molecules and radical, progresses, which resulted in the scavenging of the radical by hydrogen donation. It is visually noticeable as a discoloration from purple to yellow.

In the study, antiradical activities of extracts and standard antioxidants such as BHA, BHT and $\alpha-$ tocopherol were determined by using DPPH. method. Scavenging effect values of extracts, BHA, BHT and $\alpha$-tocopherol at different concentrations are given Figure 2, which illustrates a decrease in the concentration of DPPH radical due to the scavenging ability of extracts, except watermelon-water, and standards. The scavenging effect of extracts and standards on the DPPH. decreased in the order of $\alpha$-tocopherol $>$ BHA $=$ watermelon-ethanol $>$ watermelon seed-ethanol $>$ watermelon-acetone $>$ BHT > watermelon seed-water $>$ watermelon seedacetone, at the highest concentration. 
CBÜ F Bil. Dergi., Cilt 13, Sayı 1, 2017, 139-147 s

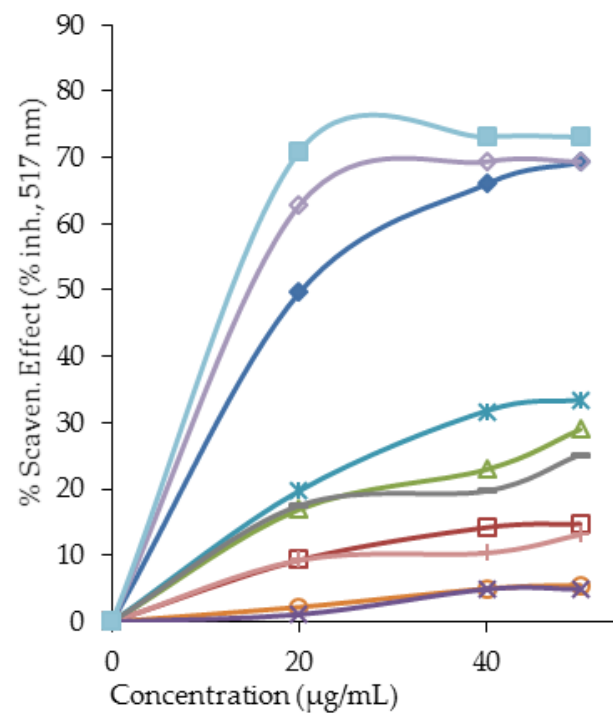

$\rightarrow$ W.Eth.

$\simeq$ W.Ace.

$\multimap$ W.Pe.

$\because$ WS.Wa

$\rightarrow$ WS.Eth

- WS.Ace

-WS.Pe.

BHT

$\leadsto$ BHA

$-\alpha-$

T.pherc

Figure 2. Scavenging effect of extracts, BHT, BHA and $\alpha$-tocopherol at different concentrations (20-40$50 \mu \mathrm{g} / \mathrm{mL})$.

\subsection{Ferrous ion chelating activity}

The chelating effect towards ferrous ions by the extracts and standards was determined. Ferrous ion can form quantitatively complexes with $\mathrm{Fe}^{2+}$. In the presence of chelating agents, the complex formation is disrupted with the result that the red color of the complex is decreased. Measurement of color reduction, therefore, allows estimation of the chelating activity of the coexisting chelator.[34] Transition metals have pivotal role in the generation oxygen free radicals in living organism. The ferric iron $\left(\mathrm{Fe}^{3+}\right)$ is a relatively biological inactive form of iron. However, it can be reduced to the active $\mathrm{Fe}^{2+}$, depending on condition, particularly $\mathrm{pH}$ [35] and oxidized back through Fenton type reactions with the production of hydroxyl radical or Haber-Weiss reactions with superoxide anions. The production of these radicals may lead to lipid peroxidation, protein modification and DNA damage. Chelating agents may not activate metal ions and potentially inhibit the metal-dependent processes.[36] Also, the production of highly active ROS such as $\mathrm{O}_{2}-, \mathrm{H}_{2} \mathrm{O}_{2}$ and $\mathrm{OH}$ are catalyzed by free iron through Haber-Weiss reactions:

$\mathrm{O}_{2}+\mathrm{H}_{2} \mathrm{O}_{2} \rightarrow \mathrm{O}_{2}+\mathrm{OH}^{-}+\mathrm{OH}$

Among the transition metals, iron is known as the most important lipid oxidation pro-oxidant due to
CBU J. of Sci., Volume 13, Issue 1, 2017, p 139-147 its high reactivity. The ferrous state of iron accelerates lipid oxidation by breaking down the hydrogen and lipid peroxides to reactive free radicals via the Fenton reactions:

$$
\mathrm{Fe}^{2+}+\mathrm{H}_{2} \mathrm{O}_{2} \rightarrow \mathrm{Fe}^{3+}+\mathrm{OH}^{-}+\mathrm{OH}
$$

$\mathrm{Fe}^{3+}$ ion also produces radicals from peroxides, even though the rate is tenfold less than that of $\mathrm{Fe}^{2+}$ ion, which is the most powerful pro-oxidant among the various types of metal ions.[37]

Ferrous ion chelating activities of extracts and standard antioxidants such as EDTA and $\alpha$ tocopherol at different concentrations are shown in Figure 3, which illustrates a decrease in the concentration of metal-chelate complex due to the metal chelating effect of only for watermelon seedethanol, watermelon seed-water and watermelonwater extracts. Low absorbance at $562 \mathrm{~nm}$ indicates high metal chelating activity. The metal chelating effect of extracts and standards decreased in the order of EDTA $>\alpha$-tocopherol $>$ watermelon seedethanol > watermelon seed-water $>$ watermelonethanol, which were $87.3 \%, 74.2 \%, 62.7 \%, 48.7 \%$, $25.8 \%$, at the highest concentration, respectively.

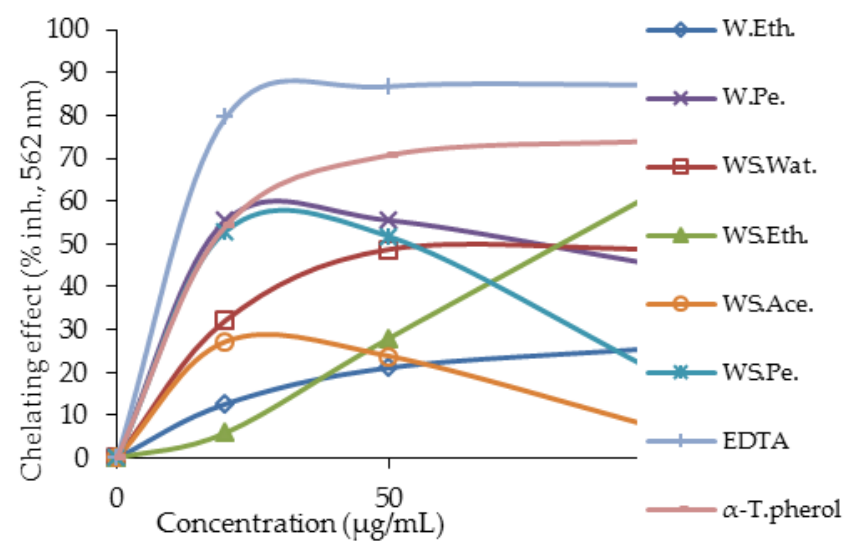

Figure 3. Metal chelating effect of different amount of the extracts, EDTA and $\alpha$-tocopherol on ferrous ions.

\section{Conclusion}

The present study is the first to report the antimicrobial activities and anti-oxidant properties of watermelon fruit and seed extracts. The extracts demonstrated a wide range of anti-microbial activity against various pathogens, generating inhibition- 
CBÜ F Bil. Dergi., Cilt 13, Sayı 1, 2017, 139-147 s

zone diameters of up to $30 \mathrm{~mm}$.

According to data obtained from the anti-oxidant evaluation, the ethanolic extract of watermelon fruit and seed demonstrated marked reducing power, DPPH-scavenging activity and iron-binding ability. Furthermore, watermelon seed-water extract possessed moderate activity for all three methods.

In conclusion, these results highlight that watermelon fruit and seed extracts have potential for the development of efficient, safe and cost-effective natural anti-oxidant compounds for application in the functional food industries. However, further studies to isolate the putative biochemical compounds from the extracts are needed.

\section{References}

[1] Levy, S. Microbial resistance to antibiotics: an evolving and persistent problem. The Lancet. 1982; 320 (8289), 83-88.

[2] Dulger, B.; Ceylan, M.; Alitsaous, M. Artemisia absinthium l. (Pelin)'un Antimikrobiyal aktivitesi. Tr. J. of Biology. 1999; 23, 377-384.

[3] Furigaa, A., Lonvaud-Funelb, A.; Badeta, C. In vitro study of antioxidant capacity and antibacterial activity on oral anaerobes of a grape seed extract. Food Chemistry. 2009; 113, 1037-1040.

[4] Xanthopoulou, M.N.; Nomikos, T.; Fragopoulou, E.; Antonopoulou, S. Antioxidant and lipoxygenase inhibitory activities of pumpkin seed extracts. Food Research International. 2009; 42, 641-646.

[5] Goncagul, G.; Ayaz, E.; Antimicrobial effect of garlic (Allium sativum) and traditional medicine. J Anim Vet Adv. 2010; 9, 1-4.

[6] Kchaou, W.; Abbès, F.; Mansour, R.B.; Blecker, C.; Attia, H.; Besbes, S. Phenolic profile, antibacterial and cytotoxic properties of second grade date extract from Tunisian cultivars (Phoenix dactylifera L.). Food chemistry. 2016; 194, 1048-1055.

[7] Madhavi, D.L.; Salunkhe, D.K.; Toxicological aspects of food antioxidants. In D. L. Food antioxidants, Marcel Dekker Inc., New York. 1995; 267 p.
CBU J. of Sci., Volume 13, Issue 1, 2017, p 139-147 [8] Jayaprakasha, G.K.; Rao,, L.J. Phenolic constituents from the lichen Parmotrema stuppeum (Nyl.) Hale and their antioxidant activity. Zeitschrift für Naturforschung. 2000; C 55, 1018-1022.

[9] Smid, E.J.; Gorris, L.G.; Natural antimicrobials for food preservation. Food Science and Technology-New York-Marcel Dekker. 1999; 285-308.

[10] Yilmaz, Y. Novel uses of catechins in foods. Trends in Food Science \& Technology. 2006; 17, 64-71.

[11] Gönenc, T.; Kayalar, H.; Erdogan, T.; Kivcak, B.;, Taze ve hazir meyve sularinda karşilastirmali $\alpha$-tokoferol miktar tayini ve antioksidan aktivite arastirmasi. Turkish Journal of Biochemistry/Turk Biyokimya Dergisi. 2014; $39,215-220$.

[12] Dogmuş, D.; Durucasu, İ. Keten tohumu çeşitlerinin n-bütanol fraksiyonlarının fenolik bileşenlerinin antioksidan aktivitesi. Celal Bayar University Journal of Science. 2013; 9, 1.

[13] Eren, E. Bazi sogansi bitkilerin antioksidan aktivitelerinin belirlenmesi, Yüksek lisans tezi, Sakarya Üniversitesi Fen Bilimleri Enstitüsü. 2011.

[14] Espin, S.; Gonzalez-Manzano, S.; Taco, V.; Poveda, C.; Ayuda-Durán, B.; Gonzalez-Paramas, A.M.; SantosBuelga, C. Phenolic composition and antioxidant capacity of yellow and purple-red Ecuadorian cultivars of tree tomato (Solanum betaceum Cav.). Food chemistry. 2016; 194, 1073-1080.

[15] Ariduru, R.; Arabaci, G. Cigertaze Otu (Salvia officinalis) Bitkisinin Antioksidan Aktivitesinin Belirlenmesi. Sakarya Universitesi Fen Bilimleri Enstitusu Dergisi. 2013; 17, 2.

[16] Isbilir, S.S. Yapraklari salata-baharat olarak tuketilen bazi bitkilerin antioksidan aktivitelerinin incelenmesi. Doktora Tezi, Trakya Universitesi Fen Bilimleri Enstitusu. 2008.

[17] Mogotlane, E.A.; Mokwala, P.W. Amino acid and mineral composition of indigenous watermelon (Citrullus lanatus (Thunb) Matsum. and Nakai) landrace seeds from the Sekhukhune and Capricorn districts in the Limpopo Province. South African Journal of Botany. 2016; 103, 333.

[18] Wani, A.A.; Sogi, D.S.; Singh, P.; Shivhare, U.S. Characterization and functional properties of watermelon (Citrullus lanatus) seed protein isolates and 
CBÜ F Bil. Dergi., Cilt 13, Sayı 1, 2017, 139-147 s

salt assisted protein concentrates. Food science and biotechnology. 2011; 20, 877-887.

[19] Murray, P.R.; Baron, E.; Pfaller, M.; Tenover, F.C.; Yolke, R.H. Manual Clinical Microbiology. ASM, Washington DC. 1995; 1356 p.

[20] Sacchetti, G.; Maietti, S.; Muzzoli, M.; Scaglianti, M.; Manfredini, S. Radice $\mathrm{M}$ and Bruni R Comparative evaluation of 11 essential oils of different origin as functional antioxidants, antiradicals and antimicrobials in foods. Food chemistry. 2005; 91, 621-632.

[21] Oyaizu, M. Studies on products of browning reaction--antioxidative activities of products of browning reaction prepared from glucosamine. Eiyogaku zasshi= Japanese journal of nutrition. 1986; 44, 307-316.

[22] Blois, M.S. Antioxidant determinations by the use of a stable free radical. Nature. 1958; 181, 1199-1200.

[23] Dinis, T.C.; Madeira, V.M.; Almeida, L.M. Action of phenolic derivatives (acetaminophen, salicylate, and 5aminosalicylate) as inhibitors of membrane lipid peroxidation and as peroxyl radical scavengers. Archives of biochemistry and biophysics. 1994; 315, 161-169.

[24] Sanogo, R.; Diallo, D.; Diarra, S.; Ekoumou, C.; Bougoudogo, D. Activité antibactérienne et antalgique de deux recettes traditionnelles utilisées dans le traitement des infections urinaires et la cystite au Mali. Mali Médical. 2006; 21, 18-24.

[25] Ammar, I.; Ennouri, M.; Khemakhem, B.; Yangui, T.; Attia, H. Variation in chemical composition and biological activities of two species of Opuntia flowers at four stages of flowering. Industrial Crops and Products. 2012; 37, 34-40.

[26] Taguri, T.; Tanaka, T.; Kouno, I. Antimicrobial activity of 10 different plant polyphenols against bacteria causing food-borne disease. Biological and Pharmaceutical Bulletin. 2004; 27, 1965-1969.

[27] Al-Habib, A.; Al-Saleh, E.; Safer, A.M.; Afzal, M. Bactericidal effect of grape seed extract on methicillinresistant Staphylococcus aureus (MRSA). The Journal of toxicological sciences. 2010; 35, 357-364.

[28] Alan, L.; Miller, N.D. Antioxidant flavonoids, function and clinical usage. Alternative Medicine Review. 1996; 1, 4-10.
CBU J. of Sci., Volume 13, Issue 1, 2017, p 139-147

[29] Chung, Y.C.; Chang, C.T.; Chao, W.W.; Lin, C.; Chou, S.T.; Antioxidative activity and safety of the 50 ethanolic extract from red bean fermented by Bacillus subtilis IMR-NK1. Journal of Agricultural and Food Chemistry. 2002; 50, 2454-2458.

[30] Gulcin, I. Antioxidant and antiradical activities of Lcarnitine. Life sciences. 2006; 78, 803-811.

[31] Min, D.B. Lipid oxidation of edible oil. In Food Lipids Chemistry, Nutrition, and Biotechnology, Marcel Dekker Inc., New York. 1998; 283-296 p.

[32] Baumann, J.; Wurn, G.; Bruchlausen, V. Prostaglandin synthetase inhibiting $\mathrm{O}_{2}$-radical scavenging properties of some flavonoids and related phenolic compounds. Naunyn-Schmiedeberg's Archives of Pharmacology 1979; $308,27$.

[33] Soares, J.R.; Dinis, T.C.; Cunha, A.P.; Almeida, L. Antioxidant activities of some extracts of Thymus zygis. Free radical research. 1997; 26, 469-478.

[34] Yamaguchi, F.; Ariga, T.; Yoshimura, Y.; Nakazawa, $\mathrm{H}$. Antioxidative and anti-glycation activity of garcinol from Garcinia indica fruit rind. Journal of agricultural and food chemistry. 2000; 48, 180-185.

[35] Strlič, M.; Radovič, T.; Kolar, J.; Pihlar, B. Anti-and prooxidative properties of gallic acid in fenton-type systems. Journal of Agricultural and Food Chemistry. 2002; 50, 6313-6317.

[36] Finefrock, A.E.; Bush, A.I.; Doraiswamy, P.M. Current status of metals as therapeutic targets in Alzheimer's disease. Journal of the American Geriatrics Society. 2003; 51; 1143-1148.

[37] Calis, I.; Hosny, M.; Khalifa, T.; Nishibe, S. Secoiridoids from Fraxinus angustifolia. Phytochemistry. 1993; 33, 1453-1456. 